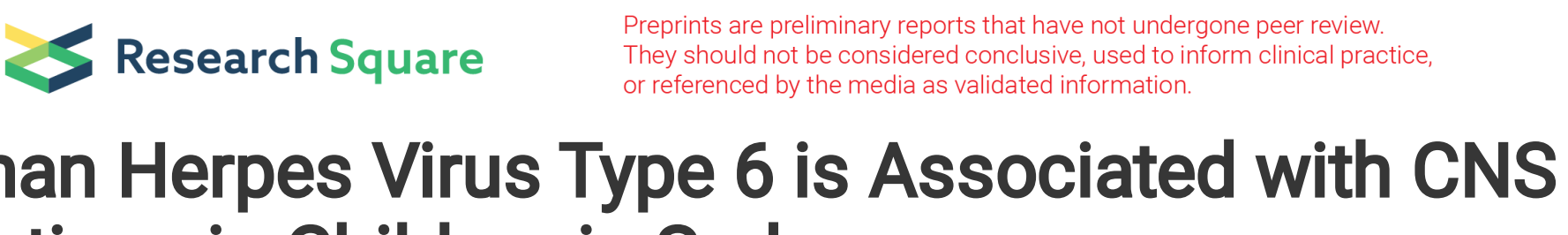 Human Herpes Virus Type 6 is
Infections in Children in Sudan
}

Nada Abdelghani Abdelrahim ( $\square$ nada.ghani@hotmail.com )

Nile University https://orcid.org/0000-0001-8736-1148

\section{Nahla Mohammed}

Umea University Faculty of Medicine: Umea Universitet Medicinska fakulteten

\section{Magnus Evander \\ Umea University \\ Clas Ahlm \\ Umea University}

Imad Mohammed Fadl-Elmula

Alneelain University, Assafa Academy

\section{Research note}

Keywords: HHV-6, Viral Neuroinfections, Viral Meningitis, Aseptic Meningitis, Real-Time PCR

Posted Date: December 17th, 2020

DOl: https://doi.org/10.21203/rs.3.rs-127726/v1

License: (c) (1) This work is licensed under a Creative Commons Attribution 4.0 International License.

Read Full License 


\section{Abstract}

\section{Objective}

HHV-6 is increasingly recognized as febrile agent in children, however, less is known in sub-Saharan African countries. In here, we aimed to investigate the involvement of HHV-6 in pediatric CNS infections in Khartoum, Sudan. This report is part of a larger study on the microbial aetiologies of CNS infections in this population.

\section{Results}

Out of 503, 13 (2.6\%) CSF specimens were positive for HHV-6 DNA which constituted 33\% (13/40) of cases with proven infectious meningitis. Median Ct for all HHV-6 positive specimens was 38 with range of 31.9 to 40.8 . Median virus copy was $281.3 / \mathrm{PCR}$ run ( $1 \times 10^{5}$ virus copies/ml CSF) with range of 30 to $44 \times 10^{3}$ copies/PCR run ( $12 \times 10^{3}$ and $18 \times 10^{6}$ virus copies/ml CSF). All positive patients presented with fever, vomiting and $86 \%$ with seizures. Male to female ratio was $1: 1 ; 50 \%$ were toddlers, $42 \%$ infants and $8 \%$ teenagers. Most (83\%) were admitted in the dry season and $17 \%$ in the rainy season. CSF leukocytosis was seen in $33 \%$. Normal and low CSF glucose levels were seen in $86 \%$ and $14 \%$, respectively. CSF proteins levels were low in $14 \%$ and high in $43 \%$. In conclusion, HHV- 6 is common in CNS infections in children in Sudan.

\section{Introduction}

HHV-6 is major cause of acute febrile illnesses in young children [1]; most are infected by age of three [2]. After primary infection, HHV-6 persists in salivary glands and remains latent in leukocytes [3]. Immunosuppression can lead to virus reactivation and various complications can occur, including CNS disease [3]. CNS disease can also occur in primary infections, especially in young immunocompetent children with fever and seizures $[4,5]$. In this matter, several authors described the major role the virus could play as a cause of pediatric neuroinfections [6-11].

In the absence of primary infection, the key finding linking HHV-6 to CNS infections is detection of viral DNA in CSF by PCR; indicating active replication. This interpretation has been questioned in view of the phenomenon of HHV-6 chromosomal integration $[12,13]$. HHV- 6 is the only human herpes virus found integrated into human genome and can be transmitted vertically from parent to child [14]. Such individual is easily identifiable, since every leukocyte contains viral sequences and there are thus characteristically persistent high levels of HHV-6 DNA in both serum and whole blood $[12,13]$. In contrast, integrated HHV-6 DNA is highly unexpected in normal cell-free body compartments, including CSF $[11,13,15]$. Ward [16] stated that viral load should be high to identify a condition as chromosomal integration and low virus copies would indicate an infection.

The outcome for HHV-6 infection is generally favorable, with most patients recovering fully. Nevertheless, mild to moderate neurological impairment as well as death due to complications has been reported [22, 
23]. Little is known on HHV-6 infections in sub-Saharan Africa, and the infection has never been investigated in Sudan. We, therefore, intended to identify the involvement of HHV-6 (among other microbial aetiologies reported elsewhere) in CNS infections in large group of children in Khartoum, Sudan.

\section{Methodology}

\section{Study Materials}

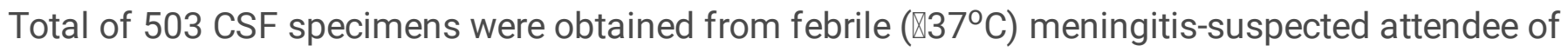
Omdurman Hospital for Children in Khartoum, Sudan. Patients ages 0 to 15 years who were admitted in all seasons of 2010 were included. Clinical and demographic data were obtained from hospital records. Routine CSF analyses were performed at the Microbiology Laboratory of Omdurman Hospital. An aliquot of CSF was frozen in $-80^{\circ} \mathrm{C}$ for further analysis for HHV-6 DNA at the department of Clinical Microbiology, Umeå University, Sweden. Permission to collect data and specimens was granted from hospital authorities. Ethical clearance was obtained from the Ethical Committee Board of Al-Neelain University.

\section{HHV-6 DNA Analysis}

QIAampUltraSensVirusTechnology (Qiagen ${ }^{\circledR}$ ) was used to extract viral DNA in $1 \mathrm{~mL}$ CSF following the manufacturer recommendations. Pure viral nucleic acids were eluted in $30 \mu \mathrm{llow}$-salt buffer AVE twice. Each elute $(60 \mu \mathrm{l})$ was divided into two aliquots and preserved at $-80^{\circ} \mathrm{C}$.

Viral gDNA amplification and detection was performed by real-time analysis using Applied Biosystems ${ }^{\circledR} 7900 \mathrm{HT}$ Fast Real-Time PCR system and TaqMan ${ }^{\circledR}$ probe (reporter dye FAM ${ }^{\mathrm{Tm}}$ on $5^{\prime}$ end and quencher dye TAMRA ${ }^{\mathrm{TM}}$ on $3^{\prime}$ end). Forward and reverse primers (Table S1) and probes (DNATechnology ${ }^{\circledR}$ ) were diluted to reach final working concentration of $25 \mu \mathrm{M}$ (standardized concentration by Umeå University Hospital). Commercially provided oligonucleotide products were diluted to the suitable working solution and the recommendation of QuantiTect ${ }^{\circledR} Q P C R$ Protocol was followed. Master mix was prepared for HHV-6 primers as follow: $12.5 \mu \mathrm{l}$ of 2x QuantiTect ${ }^{\text {TM }}$ Probe PCR Master Mix

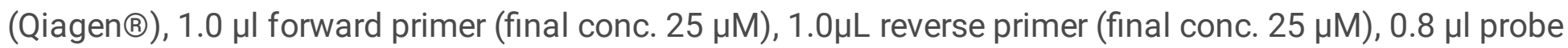
(final conc. $20 \mu \mathrm{M}$ ) and $7.2 \mu \mathrm{l}$ RNAse-free water (Ambion ${ }^{\circledR}$ ) were added into $2.5 \mu$ lemplate gDNA to complete total reaction volume of $25 \mu \mathrm{l}$ per single PCR reaction. The mixture was pulse-vortexed and centrifuged briefly. $22.5 \mu \mathrm{l}$ single reaction mix was transferred into MicroAmp ${ }^{\text {TM}}$ Optical-96-Well-ReactionPlate (AppliedBiosystems ${ }^{\circledR}$ ) to which $2.5 \mu$ template gDNA was added to reach total volume of $25 \mu \mathrm{l}$ per one reaction. Each PCR reaction plate included 8 standard dilutions, one negative reverse transcriptase, one non-template control containing $\mathrm{ddH}_{2} \mathrm{O}$ and duplicates or triplicates of each experimental DNA template.

Standard used for PCR had $5 \times 10^{6}$ (5E6) virus copies (obtained from Virology Department, Umeå University Hospital), followed by $1 / 10$ serial dilutions to reach concentrations of 5E5, 5E4, 5E3, 5E2, 5E1, 
5 and 1 virus copy.

Real-time cycler thermal condition was as follow: heating $\left(50^{\circ} \mathrm{C} / 2 \mathrm{~min}\right)$, HotStarTaq ${ }^{\circledR}$ DNA Polymerase initial activation $\left(95^{\circ} \mathrm{C} / 10 \mathrm{~min}\right)$, denaturation $\left(94^{\circ} \mathrm{C} / 15 \mathrm{sec}\right)$, annealing and extension $\left(60^{\circ} \mathrm{C} / 60 \mathrm{sec}\right)$. Repeated 45 times for approximately 90 minutes. Data were analyzed using ABI-7900HT-SDS-Plate-Utility Version-2.4 software.

\section{Results}

\section{Clinical, demographic and conventional laboratory findings for patients with positive CSF HHV-6 DNA}

All patients with clinical data $(100 \% ; 7 / 7 ;\{6$ cases out of total 13 had missing clinical data $\})$ presented

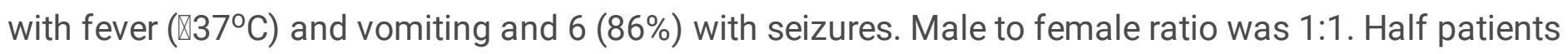
were toddlers, $42 \%(5 / 12 ;\{1$ missing case $\})$ infants and $8 \%(1 / 12)$ a 15 years old. Most patients (83\%; 10/12) admitted to the hospital in the dry season (December to June) and $17 \%(2 / 12)$ in the rainy season (July to August). CSFs from 42\% (5/12) were traumatic; cytological and chemical analyses were not performed. Remaining 58\% (7/12) were clear; 33\% (1/7) showed increased CSF WBCs (50cells $/ \mathrm{mm}^{3}$ ) with $60 \%$ lymphocytosis, remaining $67 \%(6 / 7)$ showed normal count ( $<5$ cells $/ \mathrm{mm}^{3}$ ). CSF glucose levels for most specimens $(86 \% ; 6 / 7)$ were normal $(45-100 \mathrm{mg} / \mathrm{dl})$ and one specimen $(14 \%)$ was low (30 mg/dl). CSF proteins level was high (> $45 \mathrm{mg} / \mathrm{dl})$ in $43 \%(3 / 7)$, normal $(14-45 \mathrm{mg} / \mathrm{dl})$ in $43 \%(3 / 7)$ and low $(11 \mathrm{mg} / \mathrm{dl})$ in $14 \%$ (1/7) (Table 1). All $13 \mathrm{HHV}-6$ positive cases did not show evidence of rapidgrowing-bacteria co-existing in CSF on Gram's stain and in vitro bacterial culture. However, 23\% (3/13) were positive for other non-cultivable microbes. All patients $(100 \% ; 7 / 7)$ were recovered and discharged. 
Table 1

Demographic, Clinical and Conventional Laboratory Data for HHV-6 Positive Patients

\begin{tabular}{|c|c|c|c|c|}
\hline \multirow{3}{*}{$\begin{array}{l}\# \\
1\end{array}$} & \multicolumn{2}{|c|}{ Demographic Data $(n=12)^{(1)}$} & \multirow{2}{*}{$\begin{array}{l}\text { Number of Cases } \\
\left(\% \text { Out of } 12^{(1)}\right) \\
6(50 \%)\end{array}$} & \multirow{2}{*}{$\begin{array}{l}\text { \% Out of } 503^{(1)} \\
1.2 \%\end{array}$} \\
\hline & Sex & Males & & \\
\hline & & Females & $6(50 \%)$ & $1.2 \%$ \\
\hline \multirow[t]{3}{*}{2} & Age & $\otimes 12$ Months & $5(42 \%)$ & $1 \%$ \\
\hline & & 1 to 5 Years & $6(50 \%)$ & $1.2 \%$ \\
\hline & & $\otimes 10$ Years & $1(8 \%)$ & $0.2 \%$ \\
\hline \multirow[t]{3}{*}{3} & Season of Admission & Winter (November-February) & $3(25 \%)$ & $0.6 \%$ \\
\hline & & Summer (Mars-June) & $7(58 \%)$ & $1.4 \%$ \\
\hline & & Autumn (July-August) & $2(17 \%)$ & $0.4 \%$ \\
\hline \# & \multicolumn{2}{|c|}{ Signs \& Symptoms $(n=7)(2)$} & \multicolumn{2}{|c|}{ Number of Cases (\% Out of $7^{(2)}$ ) } \\
\hline 1 & \multicolumn{2}{|l|}{ Fever } & \multicolumn{2}{|l|}{$7(100 \%)$} \\
\hline 2 & \multicolumn{2}{|l|}{ Seizures } & \multicolumn{2}{|l|}{$6(86 \%)$} \\
\hline 3 & \multicolumn{2}{|l|}{ Vomiting } & \multicolumn{2}{|l|}{$7(100 \%)$} \\
\hline 4 & \multicolumn{2}{|l|}{ Chills } & \multicolumn{2}{|l|}{$1(14 \%)$} \\
\hline 5 & \multicolumn{2}{|l|}{ Stiff neck } & \multicolumn{2}{|l|}{$1(14 \%)$} \\
\hline$\#$ & \multicolumn{2}{|c|}{ Conventional Lab Results $(n=12)$} & \multicolumn{2}{|c|}{$\begin{array}{l}\text { Number of Cases [\% Out of } 12^{(1)} \text { ] } \\
\left(\% \text { Out of } 7^{(3)}\right)\end{array}$} \\
\hline \multirow[t]{2}{*}{1} & \multirow[t]{2}{*}{ CSF WBC Count } & Normal (<5cells/mm3) & \multicolumn{2}{|l|}{$6[50 \%](86 \%)$} \\
\hline & & Increased (= 50 cells/mm3) & \multicolumn{2}{|l|}{1 [8\%] (14\%) } \\
\hline \multirow[t]{2}{*}{2} & \multirow[t]{2}{*}{ CSF Glucose Level } & Normal (45-100 mg/dl) & \multicolumn{2}{|l|}{6 [50\%] (86\%) } \\
\hline & & Decreased $(\llbracket 30$ mg/dl) & \multicolumn{2}{|l|}{1 [8\%] (14\%) } \\
\hline \multirow[t]{3}{*}{3} & \multirow[t]{3}{*}{ CSF Protein Level } & Normal (14-45 mg/dl) & \multicolumn{2}{|l|}{3 [25\%] (43\%) } \\
\hline & & Increased ( $₫ 45$ mg/dl) & \multicolumn{2}{|l|}{3 [25\%] (43\%) } \\
\hline & & 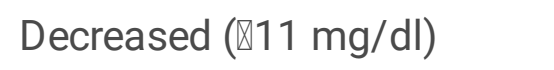 & \multicolumn{2}{|l|}{$1[8 \%](14 \%)$} \\
\hline
\end{tabular}


\# Demographic Data $(n=12){ }^{(1)}$

(\% Out of $12^{(1)}$ )

(2) Clinical data is available for 7 (54\%) out of total 13 HHV-6 positive cases

(3) Five (42\%) out of the $12 \mathrm{CSF}$ specimens were traumatic therefore cell count, glucose and protein concentrations were not estimated

Table 2

Ct and Virus Load for HHV-6 Positive Individual CSF Specimens Using Quantitative TaqMan Real-Time PCR

\begin{tabular}{|lll|}
\hline Sample ID & Ct & $\begin{array}{l}\text { Virus Quantity } \\
\text { Per PCR run }\end{array}$ \\
\hline 1 & 38.03 & $32 \times 10^{3}$ \\
\hline 2 & 39.37 & $1 \times 10^{2}$ \\
\hline 3 & 40.83 & 30 \\
\hline 4 & 37.31 & 527 \\
\hline 5 & 40.13 & 54 \\
\hline 6 & 38.38 & 221 \\
\hline 7 & 38.09 & 281 \\
\hline 8 & 34.99 & $3.5 \times 10^{3}$ \\
\hline 9 & 37.64 & 69 \\
\hline 10 & 36.77 & 818 \\
\hline 11 & 40.59 & 37 \\
\hline 12 & 35.65 & $2 \times 10^{3}$ \\
\hline 13 & 31.87 & $44 \times 10^{3}$ \\
\hline
\end{tabular}

\section{Real-time PCR findings}

13/503 (2.6\%) CSF specimens were positive for HHV-6 DNA by PCR. Median Ct for all positive specimens was 38 with range 31.9 to 40.8 . Median virus copy was $281.3 / \mathrm{PCR}$ run $\left(1 \times 10^{5}\right.$ virus copies $\left./ \mathrm{ml} \mathrm{CSF}\right)$ with range 30 to $44 \times 10^{3}$ copies/PCR run $\left(12 \times 10^{3}\right.$ and $18 \times 10^{6}$ virus copies/ml CSF). Individual PCR data for 
all 13 positive specimens are shown in table (2). Standard dilutions with viral copies of 5E6 to 5E2 produced amplification curves between $\mathrm{Ct} 24$ to $\mathrm{Ct} 36$. The generated standard curve plot showed repeated perfect negative association between $\mathrm{Ct}$ and viral quantity in all PCR runs.

Final cases classification based on clinical and molecular findings is shown on table (3).

Table 3

Classification of Cases Based on Clinical and Molecular Findings

\begin{tabular}{|c|c|c|c|c|}
\hline \multirow[t]{2}{*}{$\#$} & \multirow[t]{2}{*}{ Defined Groups } & \multicolumn{2}{|c|}{ Cases out of $503^{(1)}$} & \multirow[t]{2}{*}{$\%$ Out of $40^{(2)}$} \\
\hline & & $\%$ & Frequency & \\
\hline 1 & Proven infectious meningitis ${ }^{(3)}$ & $8 \%$ & $40^{(2)}$ & $100 \%$ \\
\hline 2 & Proven viral meningitis & $3.2 \%$ & $16^{(4)}$ & $40 \%$ \\
\hline 3 & HHV-6 meningitis & $2.6 \%$ & 13 & $33 \%$ \\
\hline \multicolumn{5}{|c|}{$\begin{array}{l}\text { (1) Total number of febrile suspected patients who attended the hospital during the study period anc } \\
\text { were subjected to LP }\end{array}$} \\
\hline \multicolumn{5}{|c|}{$\begin{array}{l}\text { (2) } 17 \text { cases with positive microbial origin -but with normal cellular count- along with all } 23 \text { cases with } \\
\text { CSF pleocytosis with or without positive microbial etiology }\end{array}$} \\
\hline \multicolumn{5}{|c|}{ (3) This information has been shared in our previous publication 20} \\
\hline
\end{tabular}

\section{Discussion}

HHV-6 is becoming increasingly recognized as emerging CNS pathogen, nevertheless, it has never been investigated in Sudan and very little is known in sub-Saharan Africa and the meningitis belt. In this study, HHV-6 DNA was identified in CSF of $2.6 \%$ of pediatric patients with suspected meningitis. Close findings of $1.8 \%(27 / 1,482)$ and $1.5 \%(1 / 65)$ were reported from New York, USA [21] and Southern Iran [24], respectively.

Another study in New York [11] revealed significantly higher prevalence of $40 \%$ (14/35) in patients with CNS infections who tested negative for other CNS pathogens. Among well-defined groups in our study, the prevalence was also high accounting for $33 \%$ out of 40 cases with proven infectious meningitis (Table 3). Unlike Yao [11] approach, we did not exclude cases with other detected CNS pathogens because of possible co-infections, as frequently reported [21, 25-27]. In fact, we were able to identify mixed microbial infections in three cases.

Primary HHV-6 infection almost invariably occurs in the first 2 years of life $[5,28,29]$, but rare cases of CNS infections, presumed due to HHV- 6 reactivation, have been reported in immunocompetent older 
children and adults [22]. Among $24 \mathrm{HHV}-6$ positive patients in Tavakoli study [21], 42\% were infants $\leq$ 3 years and $12.5 \%$ were teenagers $\leq 17$ years. Out of our $13 \mathrm{HHV}-6$ positive cases; $92 \%$ were infants $\leq$ 2.3 years and $8 \%$ was a 15 years old. The ratio of males to females was 1:1 which agrees with Tavakoli's findings of 1.3:1.1.

Clinical signs and symptoms in HHV-6 meningitis are not specific [30]. Tavakoli [21] reported fever in 71\%, altered mental status in $67 \%$, headache in $29 \%$ and seizures in $33 \%$. Other reported symptoms were muscle weakness, muscle pain and stiff neck; which are general symptoms for meningitis or encephalitis. We report fever and vomiting in $100 \%$ of HHV- 6 positive cases, seizures in $86 \%$, chills in $14.3 \%$ and stiff neck in $14.3 \%$. None of our patients developed skin rash being the only specific -but rare- symptom in HHV-6 meningitis [30]; other studies [21, 24] concur.

Normal CSF glucose with normal or elevated proteins is the usual finding in viral CNS infections [17], as found in this study. Unfortunately, chemical analysis of the CSF is ineffective in case of viral infections; however, its significance is in distinguishing bacterial from aseptic aetiologies which is crucial preliminary step in deciding adequate treatment. CSF leukocytosis was seen in $33 \%$. Increased numbers of CSF leukocytes $\left(\$ 5 \mathrm{cell} / \mathrm{mm}^{3}\right)$ indicates inflammation, however, normal cellular counts do not rule out viral aetiologies. In fact, normal CSF cellular counts in patients with proven CNS infections were frequently reported [17-20]. Normal CSF profile was reported in 25\% of HHV-6 positive cases by Tavakoli [21], accordingly, HHV-6 testing should not be limited to patients with abnormal CSF profiles.

Thermal cycle (Ct) is defined as the number of cycles required for the fluorescent signal to cross the threshold (exceed background level). Median Ct for our positive cases was 38 (range: 31.9-40.8). Tavakoli reported $\mathrm{Ct}$ values range 25.03 to 39.92. In quantitative real-time PCR, Ct values inversely correlate with viral loads, therefore, low $\mathrm{Ct}$ value indicates high viral load and vice versa. Our $\mathrm{Ct}$ values and viral loads were found to be significantly $(p=0.029)$ inversely correlated $(-0.6,95 \% \mathrm{Cl}:-0.9$ to -0.1$)$ indicating significant variation of viral loads among our patients. Substantial variation among viral loads in patients was also reported [21].

The phenomenon of HHV-6 chromosomal integration is in debate; while some [11-13] consider it an easily identifiable condition based on the presence or absence of nucleus containing blood cells in different body compartments, Ward [16] believes the few leukocytes that are usually present in normal CSF can reveal positive viral DNA in case of HHV-6 integration. In here, CSF was clear with no observed cells in most cases (86\%), while single case (14\%) showed increased CSF leukocytes. Ward [16] elaborated that in order to identify a condition as chromosomal integration; viral load should be high while low virus copies would indicate infection. The average concentration of CSF HHV-6 DNA in 9 children with primary infection $\left(2.4 \log _{10}\right.$ copies $\left./ \mathrm{ml}\right)$ was significantly lower than that of 21 patients with viral chromosomal integration $\left(4.0 \log _{10}\right.$ copies $/ \mathrm{ml}$ ) in Ward study. In ours, the median CSF virus concentration was $1 \times 10^{5} \mathrm{copies} / \mathrm{ml}$ with minimum and maximum virus concentrations of $12 \times 10^{3}$ and $18 \times 10^{6}$ copies/ml. While Ward [16] recommended identifying low virus copies $\left(\leq 10^{3}\right)$ as an acute HHV6 infection and high virus copies $\left(\geq 10^{4}\right)$ as chromosomal integration, Collot [31] identified viral 
integration in approximate concentrations of $10^{3}$ to $10^{6} \mathrm{copies} / \mathrm{ml}$. We identified viral concentrations as low as $10^{4}$ and as high as $10^{7}$. Others $[11,21]$ reported high CSF viral loads in patients with HHV-6 CNS infections. Some authors $[12,13]$ insist that chromosomal integration is a rare condition. Accordingly, we assume the detected HHV-6 DNA in our mostly cell-free CSF specimens is more likely to be from free replicating virus than from chromosomally integrated virus.

Febrile seizures appear to be caused by primary HHV-6 infection in infants with incidence of $13 \%$ in the United States [4]. Knowing that febrile seizures and vomiting were dominant symptoms among our population and the most frequent age group was children $\leq 2.3$ years, therefore further supporting our assumption. Despite this, and for the sake of scientific relevance, we are not ruling out the possibility of integration among our identified cases. For this reason, studies to identify the prevalence of HHV-6 integration among healthy Sudanese population are warranted.

\section{Conclusion And Limitation}

We conclude that HHV-6 CNS infection is frequent in this population (i.e. identified in one third of cases with proven infectious meningitis). A major limitation in this study is that we were unable to further genotype our identified HHV-6 DNA copies because of limited CSF volume (i.e. all available CSF was consumed in repeated testing and identifications).

\section{Declarations}

\section{Ethics approval and consent to participate}

The ethical clearance for conducting this study was obtained from the Ethical Committee Board of AlNeelain University. Permission to collect data and specimens was granted from hospital authorities. Patients were not contacted directly; data were obtained from hospital files and were kept anonymous at all stages of the study. Specimens were obtained from the hospital main laboratory after all requested tests were applied.

\section{Consent for publication}

Not applicable.

\section{Availability of data and materials}

The datasets used and/or analysed during the current study will be available from the corresponding author on reasonable request once all related articles are published.

\section{Competing interests}

We, the authors, declare that we have no competing interests with respect to the research, authorship and/or publication of this article. 


\section{Funding}

Molecular laboratory investigations were supported by the Department of Clinical Microbiology at Umeå University in Umeå, Sweden.

\section{Authors' contributions}

NA developed research questions and design, collected and managed all data, performed all laboratory work, statistical analysis and interpretation, wrote and edited the text. NM advised on the approach and methodology and guided and supervised the molecular laboratory work. ME and CA contributed on the approach and methodology, supervised the molecular laboratory work, edited and proofread the manuscript and were major contributors in the overall study. IF supervised the research process throughout; contributed in the development of research questions, design and methodology, managed all logistics and clinic based activities. All authors have read and approved the final manuscript.

\section{Acknowledgements}

We acknowledge all laboratory technologists in the Bacteriology Departments of Omdurman Hospital for Children, the National Health Laboratory and the Central Public Laboratories at the Ministry of Health for providing clinical data and specimens. We also thank the administrations of Sudan Medical and Scientific Research Institute (SUMASRI) of the University of Medical Sciences and Technology (UMST) and that of the Faculty of Medical Laboratory Sciences of Al-Neelain University in Khartoum, Sudan, for providing working space and allowing use of laboratory ware. We are indebted for the kind gesture of complete bench fee waiver that was provided by the Department of Clinical Microbiology, Umeå University in Umeå, Sweden, to perform all molecular investigations. We thank Professor Hassan Mohammed Ali for his great efforts in revising the manuscript.

\section{References}

1. Pruksananonda $P$, Hall $C B$, Insel RA, Mclntyre $K$, Pellett $P E$, Long $C E$, et al. Primary human herpesvirus 6 infection in young children. N Engl J Med 1992; 326(22):1445-0.

2. Briggs $M$, Fox J, Tedder RS. Age prevalence of antibody to human herpesvirus 6 . Lancet 1988;1(8593):1058-9.

3. Lusso P, Gallo RC. Human herpesvirus 6 in AIDS. Immunol Today 1995;16(2): 67-1.

4. Kondo K, Nagafuji H, Hata A, Tomomori C, Yamanishi K. Association of human herpesvirus 6 infection of the central nervous system with recurrence of febrile convulsions. J Infect Dis 1993;167(5):1197-0.

5. Hall CB, Long CE, Schnabel KC, Caserta MT, McIntyre KM, Costanzo MA, Knott A, Dewhurst S, Insel RA, Epstein LG. Human herpesvirus- 6 infection in children; a prospective study of complications and reactivation. N Engl J Med 1994;331(7):432-8. 
6. Koskiniemi M, Rautonen J, Lehtokoski-Lehtiniemi E, Vaheri A. Epidemiology of encephalitis in children: a 20-year survey. Ann Neurol 1991;29(5):492-9.

7. Kolski H, Ford-Jones EL, Richardson S, Petric M, Nelson S, Jamieson F, Blaser S, Gold R, Otsubo H, Heurter H, MacGregor D. Etiology of acute childhood encephalitis at The Hospital for Sick Children, Toronto, 1994-1995. Clin Infect Dis 1998;26(2):398-09.

8. Yoshikawa T, Asano Y. Central nervous system complications in human herpesvirus- 6 infection. Brain Dev 2000;22(5):307-4.

9. Whitley RJ, Gnann JW. Viral encephalitis: familiar infections and emerging pathogens. Lancet 2002;359(9305):507-3.

10. Theodore WH, Epstein L, Gaillard WD, Shinnar S, Wainwright MS, Jacobson S. Human herpes virus 6B: a possible role in epilepsy? Epilepsia 2008;49(11):1828-7.

11. Yao K, Honarmand S, Espinosa A, Akhyani N, Glaser C, Jacobson S. Detection of human herpesvirus6 in cerebrospinal fluid of patients with encephalitis. Ann Neurol 2009;65(3):257-7.

12. Clark DA, Nacheva EP, Leong HN, Brazma D, Li YT, Tsao EH, Buyck HC, Atkinson CE, Lawson HM, Potter MN, Griffiths PD. Transmission of integrated human herpesvirus 6 through stem cell transplantation: implications for laboratory diagnosis. J Infect Dis 2006;193(7): 912-6.

13. Ward KN, Leong HN, Nacheva EP, Howard J, Atkinson CE, Davies NW, Griffiths PD, Clark DA. Human herpesvirus 6 chromosomal integration in immunocompetent patients results in high levels of viral DNA in blood, sera, and hair follicles. J Clin Microbiol 2006;44(4):1571-4.

14. Tanaka-Taya K, Sashihara J, Kurahashi H, Amo K, Miyagawa H, Kondo K, Okada S, Yamanishi K. Human herpesvirus $6(\mathrm{HHV}-6)$ is transmitted from parent to child in an integrated form and characterization of cases with chromosomally integrated HHV-6 DNA. J Med Virol 2004;73(3):465-3.

15. Leong HN, Tuke PW, Tedder RS, Khalom AB, Eglin R, Atkinson CE, Ward KN, Griffiths PD, Clark DA. The prevalence of chromosomally integrated human herpesvirus 6 genomes in the blood of UK blood donors. J Med Virol 2007;79(1):45-6.

16. Ward KN, Leong HN, Thiruchelvam AD, Atkinson CE, Clark DA. Human herpesvirus 6 DNA levels in cerebrospinal fluid due to primary infection differ from those due to chromosomal viral integration and have implications for diagnosis of encephalitis. J Clin Microbiol 2007;45(4):1298-4.

17. Logan SA, MacMahon E. Viral meningitis. BMJ 2008;336(7634):36-0.

18. Big C, Reineck LA, Aronoff DM. Viral infections of the central nervous system: a case-based review. Clin Med Res 2009;7(4):142-6.

19. Lee BE, Davies HD. Aseptic meningitis. Curr Opin Infect Dis 2007;20(3):272-7.

20. Abdelrahim NA, Fadl-Elmula IM, Ali HM. Bacterial meningitis in Sudanese children; critical evaluation of the clinical decision using clinical prediction rules. BMC Pediatr 2019;19(1):319. doi: 10.1186/s12887-019-1684-3.

21. Tavakoli NP, Nattanmai S, Hull R, Fusco H, Dzigua L, Wang H, Dupuis M. Detection and typing of human herpesvirus 6 by molecular methods in specimens from patients diagnosed with encephalitis 
or meningitis. J Clin Microbiol 2007;45(12):3972-8.

22. Isaacson E, Glaser CA, Forghani B, Amad Z, Wallace M, Armstrong RW, Exner MM, Schmid S. Evidence of human herpesvirus 6 infection in 4 immunocompetent patients with encephalitis. Clin Infect Dis 2005;40(6):890-3.

23. Takanashi J, Barkovich AJ, Tada H, Takada N, Fujii K, Kohno Y. Cortical liquefaction in severe human herpesvirus 6 encephalopathy. Neurology 2006;66(3):452-3.

24. Hosseininasab A, Alborzi A, Ziyaeyan M, Jamalidoust M, Moeini M, Pouladfar G, Abbasian A, Kadivar MR. Viral etiology of aseptic meningitis among children in southern Iran. J Med Virol 2011;83(5):8848.

25. Ibrahim Al, Obeid MT, Jouma MJ, Roemer K, Mueller-Lantzsch N, Gärtner BC. Prevalence of herpes simplex virus (types 1 and 2), varicella-zoster virus, cytomegalovirus, and human herpesvirus 6 and 7 DNA in cerebrospinal fluid of Middle Eastern patients with encephalitis. J Clin Microbiol 2005;43(8):4172-4.

26. Minjolle S, Michelet C, Jusselin I, Joannes M, Cartier F, Colimon R. Amplification of the six major human herpesviruses from cerebrospinal fluid by a single PCR. J Clin Microbiol 1999;37(4):950-3.

27. Tang YW, Espy MJ, Persing DH, Smith TF. Molecular evidence and clinical significance of herpesvirus coinfection in the central nervous system. J Clin Microbiol 1997;35(11):2869-2.

28. Yoshikawa T, Suga S, Asano Y, Yazaki T, Kodama H, Ozaki T. Distribution of antibodies to a causative agent of exanthem subitum (human herpesvirus-6) in healthy individuals. Pediatrics 1989;84(4):6757.

29. Ward KN, Gray JJ, Fotheringham MW, Sheldon MJ. IgG antibodies to human herpesvirus-6 in young children: changes in avidity of antibody correlate with time after infection. J Med Virol 1993;39(2):131-8.

30. Schvoerer E, Fréchin V, Fritsch S, Freitag R, Fuchs A, Gut JP, Stoll-Keller F. Atypical symptoms in patients with herpesvirus DNA detected by PCR in cerebrospinal fluid. J Clin Virol 2006;35(4):458-2.

31. Collot S, Petit B, Bordessoule D, Alain S, Touati M, Denis F, Ranger-Rogez S. Real-time PCR for quantification of human herpesvirus 6 DNA from lymph nodes and saliva. J Clin Microbiol 2002;40(7):2445-1.

\section{Supplementary Files}

This is a list of supplementary files associated with this preprint. Click to download.

- SupplementaryFileTableS1.docx

- SupplementaryFileTableS1.docx 